\title{
Pakistan-Us Alien Associations in the Perspective of Media and Geo-Politics
}

\author{
Prof.Dr. Muhammad Ahmed Qadri \\ Former Dean, Faculty of Arts and Social Sciences, University of Karachi \\ Zeeshan Faisal Khan \\ Research Scholar, Department of International Relations, University of Karachi
}

\begin{abstract}
In Asia, the exceptionally associated accomplice of United States is Pakistan. Three essential commitments are investigated as far as Pakistan- United States contact together with the Cold Pakistan is the main exchange companion of America and requires developing its fare base in America particularly in the territory of cotton related items while allowing for the arrangement of amount organized commerce with America. To the extent worldwide harmony quality is concerned, Pakistan is constantly expected to be a critical partner of worldwide affiliation. This paper is talking about the Pakistan- United States association with regards to Media and Geopolitics particularly at the time of 2000-2015 and furthermore featured that the said association can help the monetary presentation of together the nations on one hand and upgrades the tranquility of the district on another hand.
\end{abstract}

Keywords: Pakistan, United States, Geo Politics, Media

DOI: $10.7176 / \mathrm{IAGS} / 80-03$

Publication date: February $29^{\text {th }} 2020$

\section{Introduction}

Pakistan-US subjective unions and the US target to verify strategic frame, cheerily coincided by means of Pakistan's conviction of US support (Center of Global Development, 2014). An inquisitively indistinguishable example is trailed by the pinnacle and trench inside the Pakistan-U.S affinity particularly due to the exchange of Nuclear Program growth of Pakistan. Two quick conditions had indispensable impact in Pakistan at the opportunity of Pakistan appeared looking for the US as a supporter (Abbas, 2014; Lavoy, 2005).

Since freedom, Pakistan has acknowledged nearly $\$ 70$ billion as relieve by US which is with the peak beneficiary of US support globally (Ahmed Waqas Waheed, 2017). The reality is finest that the US military supports to Pakistan armed forces has delve into Pakistan military as eminence fighting supremacy (Cohen, 2004).The guiding principle composer satiate in US financial system contain frequently marked that US bring into being is incapable to embrace several influence in the course of action of judgment building yet however take advantage of the relieve seeing that power (Ibrahim, 2009). The U.S.-Pakistan discrepancy in constructivist main beliefs together with simply short-range pragmatist agreement in severe difference to the U.S.-India longstanding union of mutually pragmatist and constructivist principles transform into the differential conduct meted out by the U.S. to India and Pakistan. The geopolitical actuality borne in the apparent capability of India as a counter-weight to China gives better dominance to an American association with India than it does to one with Pakistan. In providing Pakistan with armed forces and economic aid, the U.S. was looking for Pakistan's assistance in opposing the Soviet existence in Afghanistan.

Based on the nature of Pakistan-U.S. associations, the current requirements of both the countries and worldwide realities, it can be said without doubt that both Pakistan and the U.S. require each other at this decisive point in time. America wants to comprehend the confines of the Pakistan government and keep away from such acts which are in opposition to the summons of the state. According to American estimates, since 2001, Congress has permitted about \$20 billion Rethinking Pakistan-U.S. relations 135 for Pakistan in direct relieve and armed forces reimbursements. The figures for the money received vary from $\$ 11$ billion to $\$ 18$ billion. Pakistan has received around US \$70 billion in US overseas relieve since its beginning in 1947. This places it among the top recipients of US overseas aid just about the world. This is visibly apparent in the patterns of US support to Pakistan and the intensity of implication both states accord to economic support. 


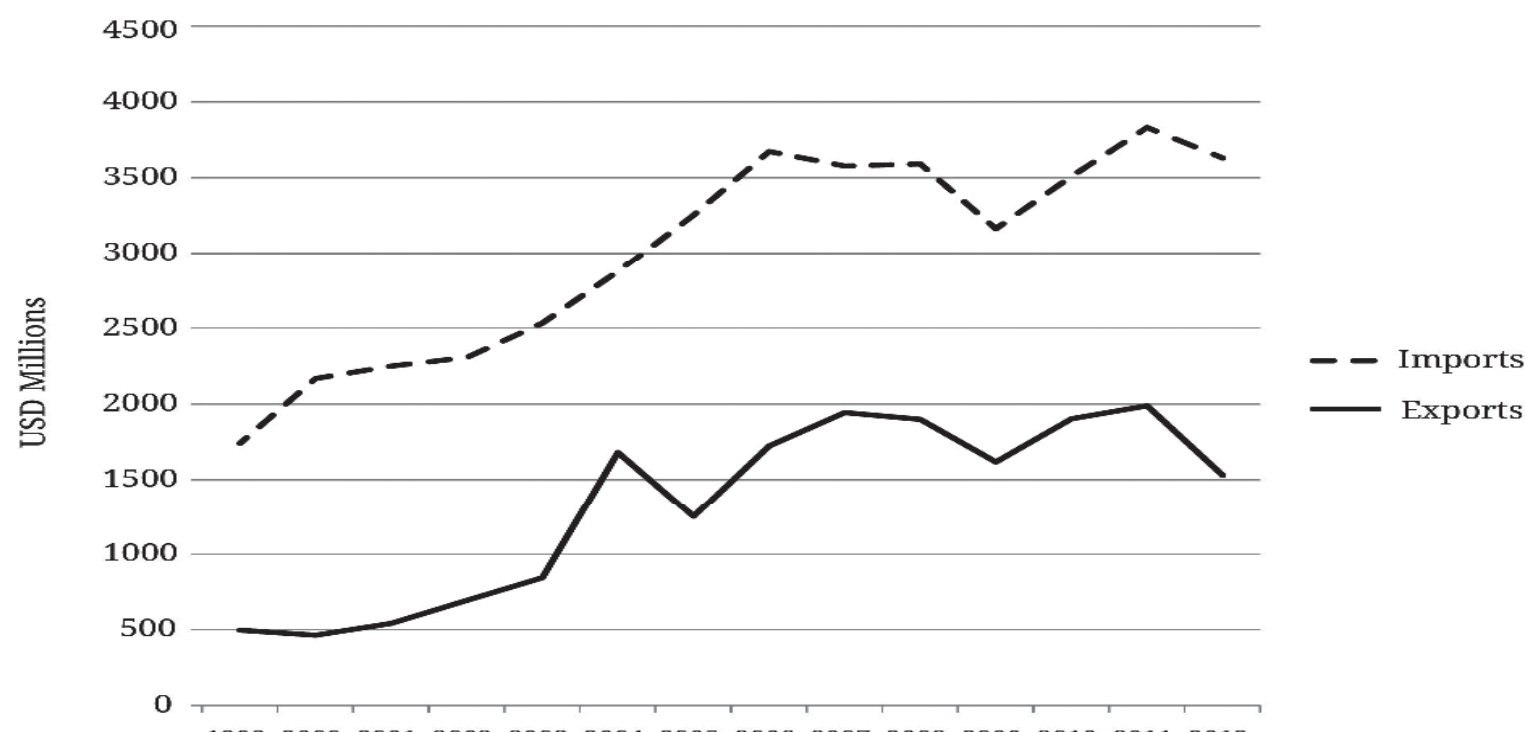

19992000200120022003200420052006200720082009201020112012

Figure1. Pakistani Exports to and Imports from the Unite States, 1999-2012 (\$US million)

Source: U.S. Census Bureau, "Pakistani exports and imports in USD millions (1985-2011)," 2010, http://www.census

Because of the American opinions in opposition to Pakistan which is expanding step by step, there is prerequisite to start a trade program with American administration in the course of the media in US and the procedure call for to enlighten American resident that Pakistan as opposed to liability fear mongering, a sufferer of it and assuming an imperative job to battle by way of. In 2005, Pakistan got $\$ 510$ million for the alleviation for quake reproduction plus the help activity embrace by means of armed forces help by US (Najam Rafique, 2011). The US objectives intended for South Asia are the essential purposes behind the connection among Pakistan and US however, the points of this connection confronted numerous good and bad times and the help to Pakistan. The absence of subjective and mechanical circumference despite the fact that Pakistan is a long ways ahead in Defense viewpoints, Pakistan can't get completely autonomous in ammo's creation (Siddiqa-Agha (1999, 2001). The exchange streams are influenced because of political interruption in different nations alongside the maintaining issues to US. Worldwide exchange is the main component to demonstrate the US reliance meant for enticing countries into the U.S. decided worldwide financial arrangement. The main objective is to change the point of US through the expansion in concealed possession (Andreasen, J. (2014). The traditional progressivism is utilized to improve the overall moderate marketplace mold by means of financial advancement, in addition to decrease the limitations of administration in monetary undertakings to build the private proprietorship. (Bit, R. K., and Kilby, C. 2008).

\section{Review of Literature}

Pakistan has received around US $\$ 70$ billion in US overseas relieve since its beginning in 1947. This places it among the top recipients of US overseas aid just about the world. This is visibly apparent in the patterns of US support to Pakistan and the intensity of implication both states accord to economic support. The United States remained mostly disconnected from Pakistan all the way through the 1990s and forced sanctions in the late 1990s while Pakistan carried nuclear tests. Connecting 2001 and 2011, the US used up more than $\$ 8.8$ billion in nonmilitary support to Pakistan. With the utmost expenditure in 2002 and after 2009. In liability as such, Washington might pick up as of considering Sino-Pakistani affiliations aimed to establish an incessant apprehension pattern and has prompted an unfaltering alliance and significant joint effort on a large number of matters (Isaac Kfir, 2014). In the time of Cold War, Pakistan stratagem significance depended on foreign affairs of worldwide associations. Two gathering frameworks of legislators and officeholders make a dismemberment of recognition; as majority rule government official see the development of developing countries as significant as growth of US financial system, however legislators recognize it as residential legislative issues and selfpretention is of unrivaled essentialness and the discussion on international affairs of worldwide affiliations appropriate so as to examine the elements which impact abroad help streams to Pakistan; in this way gathering motivation behind these elements the head purpose.(Syed Toqueer Akhter and Haider Imran, 2014).

The key uniqueness in 1970s, 1990s and 2000s era among Pakistan and US was of particular way of thinking because of the seriously broken relations between the two nations under the said times which further come up short on the US impact on Pakistan. The broad US armed forces help in overdue 1950s, the local generation has removing the consideration is diminished (International Business Publications, 2013). The center 
US sound creatures in the voting public prohibit security measures, power and populism. The foremost protection issue is parting away of intensity birthplaces and the Caspian locale is the critical overabundance reason for leftover fills. The truth can't be famished of in the circumstance of Pakistan and US common financial worry in Central Asia that really Pakistan needs to develop correspondence dealings with them. To shield monetary matters, it is vital to sustain and expand move linkages to and initiating the voting public to quicken the organizations explicitly of intensity just as characteristic assets (The Nation, 2003). In a decent amount of media reports and examination the zones where Pak-US missing prosperity are highlighted as well as discussed. Scholarly consideration in the circles of distinction of supposition is bigger than the territories where prosperity merges. Truly Pakistan is relying upon US in monetary and armed forces help and US intended to force understanding for US from side to side the Pakistan atomic program (Afridi and Bajoria, 2010).in the absence of any matters of religious conviction and political, Pakistan armed force entertained ancestral area and the overwhelming reason for Pushtun turmoil is the strategies of the US sustaining non-Pushtun under the concern of fighting in opposition to Taliban (M. Maqbool Khan Wazir, 2011). Before 2001 there were no key trade agreements linking the US and Pakistan. Textile concessions conquered the discussion for the reason that textiles are Pakistan's most important sell overseas to the United States. In economic expressions (i.e., on venture and buy and sell) Pakistan seems to be totally marginalized. If Pakistan obtained stability inside, conversely, it will be in motion nearer in the direction of the United States as its autonomous institutions get better and as education levels enhanced.

By connecting wellbeing estimates backing and armaments deals for the accomplishment of monetary result, US set out for explicit situated up of political system. (Stirs, D., and Waterman, K. 2018). As a result nations have move toward as most recent practitioners in worldwide governmental issues. Therefore region binds to offer someone the utilization of a furnish all mutually and concurrently binds like ASEM, is advancing mostly in vitality. The Globalization, reliance and regionalism is spurring in the course of worldwide governmental issues (Gaens, B., Jokela, J., and Limnell, E. (Eds.). (2009). in support of the traverse limit exchange, exchange transactions are bolstered from side to side the endeavor of a few stages. (Ahmed, N. (2018). The guide organization in Pakistan is significant alongside the every single supporting managing attracted in help union. US help is a fundamental and surely understood on looker methodology union in Pakistan and distant embody the guide inflows of US to feature its incontestability as a very critical respective supporter of Pakistan ever since long. (Khan, F. J. (2016).

\begin{tabular}{|c|c|c|c|}
\hline Industry & Location & Year & Manufacturing \\
\hline $\begin{array}{l}\text { Karachi Shipyard } \\
\text { and Engineering } \\
\text { Works (KSEW) }\end{array}$ & Karachi & $1950 \mathrm{~s}$ & $\begin{array}{l}\text { Builds F-22P Frigates, Agosta 90B Khalid Class } \\
\text { Submarine, Fast Attack Craft (Missile). Jalalat } \\
\text { Class Missile Boat and involved in shipbuilding. } \\
\text { ship repair and general engineering. }\end{array}$ \\
\hline $\begin{array}{l}\text { Pakistan } \\
\text { Aeronautical } \\
\text { Complex (PAC) }\end{array}$ & Kamra & 1973 & $\begin{array}{l}\text { Initially assembled F-6 and French Mirages. } \\
\text { Produces 'Mushak' trainer aircraft, assembly } \\
\text { of ground-based radar, the Chinese- } \\
\text { developed JF-17 lightweight fighters, K-8 } \\
\text { Karakorum advanced jet trainers. }\end{array}$ \\
\hline $\begin{array}{l}\text { Heavy Industries } \\
\text { Taxila (HIT) }\end{array}$ & Taxila & 1979 & $\begin{array}{l}\text { Comprises of six major production units, } \\
\text { involved in manufacturing, rebuilding. } \\
\text { upgrading and developing Tanks, Tank Guns } \\
\text { \& APCs, such as Tank AI-Khalid I. Tank } \\
\text { Al-Khalid, Tank Al-Zarrar, APC Talha (with } \\
\text { 12.7 mm protection), I } 25 \text { mm Smooth Bore } \\
\text { Tank Gun, Command Vehicle (SAKB). }\end{array}$ \\
\hline $\begin{array}{l}\text { Air Weapons } \\
\text { Complex (AWC) }\end{array}$ & Kamra & 1993 & $\begin{array}{l}\text { Manufactures a variety of air-delivered } \\
\text { weapons, including extended range bombs, } \\
\text { target penetration bombs and infra-red } \\
\text { search and track systems. The AWC product } \\
\text { range includes HAFR-I: Anti Runway } \\
\text { Weapon; IRST: Infra-red search and track } \\
\text { system; } 250 \mathrm{~kg} \text { pre-fragmented bomb; } 250 \\
\mathrm{~kg} \mathrm{MK-} 82 \mathrm{steel} \text { bomb; } 500 \mathrm{~kg} \text { MK- } 83 \text { steel } \\
\text { bomb; } 1000 \mathrm{~kg} \text { MK- } 84 \text { steel bomb; air burst } \\
\text { electronic fuses (impact and detonating); low/ } \\
\text { high-drag tail units; } 25 \text { lbs and } 6 \mathrm{~kg} \text { practice } \\
\text { bombs; GPS: Global positioning system; and } \\
\text { the Mushak Trainer Aircraft. }\end{array}$ \\
\hline
\end{tabular}

Source: Pakistan Senate Defence Committee and Pakistan Ministry of Defence Production.

The US appears to be collusion with Pakistan to fill a small number of needs together with the Muslims compensate to Egypt left-inclining Arab patriotism along with furthermore represented a solid risk to India in the area. The US enactment initially acknowledged the assumption of friendship in the nation however afterward unwilling the Taliban foundation dependent on their extreme fan point of view and foul contradiction of human interests" (Ahmad, 2004). To the extent US approaches for Pakistan after 9/11 is worried, there isn't surprising achievement yet appended and watched an inability to kill against western activists in addition to the decrease in the religion radicalism even is as yet a conspicuous US partner in hostile to psychological oppression endeavors 
(Mackubin Thomas Owens, 2019). The criteria are to distinguish the components for Pakistan to fight back in opposition to US weight in the territory of Pakistan atomic supremacy wellbeing matters. The US can help Pakistan in creating politically-educated, consecutively focused on strategically Pakistan and target concentrating on against Pakistan gatherings to ensure the area with worldwide matters (Pak-Us Relationship Arranged for Members and Committees of Congress, 2013). Pakistan armed forces business taking advantage from Chinese alliance.

\section{Discussion and Analysis}

Pakistan also desires persistent hold up from the worldwide Finance Institutions (IFIs) in which the US plays a big role. The two key sources for addressing the BoP issues are organizations over which the U.S. has noteworthy control: the International Monetary Fund (IMF) and the World Bank. Bordering countries are intensely anxious about Pakistan's inside steadiness as well. In amassing to the various destabilizing improvements talked about finished, US- Pakistan affiliations have been unconstructively misrepresented by two advantageous noticeable contemporary events. One concern of discussion has been self-governance of adventure for U.S. liaison in Pakistan. The essential is the presence of three collective characters bunches who administer the political living being - the armed forces, the settled world class, which incorporates the first class industrialists and the devout nation - and lead the circumstance and its assets. At hand is a measure of approaches to examine the enhancement of communal gatherings, albeit in the end the path starts by way of independence.

By high worth of its location Pakistan has the inherent potency to control safekeeping, trade and business, principles and communal state of all the four regions that contain it. As the hub of an open -ended United States proxy war, politic economic volatility and uncertainty trickled to its adjoining areas. This truth is also bright to the US. Any feasible strategy on prospect approaches for Pakistan vis a vis its associations with the USA must be aware of, and address the novel world array. The surfacing of area centers of influence and that of quasi and aspiring global

group of actors. The essentialness Pakistan armed force to U.S. dealings with Pakistan is to facilitate modern American reprisal standard accentuate the obligation to confront fundamental places of refuge, which regularly turn out in depraved regions or in fizzled/feeble states for the duration of framework structure and armed forces goings-on. Challenges of are present intended for the connections among US and Pakistan because of the misconception and outrage. U.S. core value came to think about was identified with the obstinate situation in Pakistan. Hence, U.S. strategy approaching Pakistan after 2014 epoch perceives that Islamic terrorizing is a threat to the supervision plus steadiness of the two nations, with neither having the way to comprehensively beaten the activists, requiring a bizarre arrive up to. In this manner, the new advances just before draw extra on advancing entity assurance in Pakistan. To invest by way of principal assurance as an intend to hose enrollment and against U.S., and all the further fundamentally hostile to government direction, adversary.

Based on the nature of Pakistan-U.S. associations, the current requirements of both the countries and worldwide realities, it can be said without doubt that both Pakistan and the U.S. require each other at this decisive point in time. America wants to comprehend the confines of the Pakistan government and keep away from such acts, which are in opposition to the summons of the state. According to American estimates, since 2001, Congress has permitted about \$20 billion Rethinking Pakistan-U.S. relations 135 for Pakistan in direct relieve and armed forces reimbursements. The figures for the money received vary from $\$ 11$ billion to $\$ 18$ billion.

Figure1. Pakistani Exports to and Imports from the United States, 1999-2012 (\$US million) 2010, http://www.census

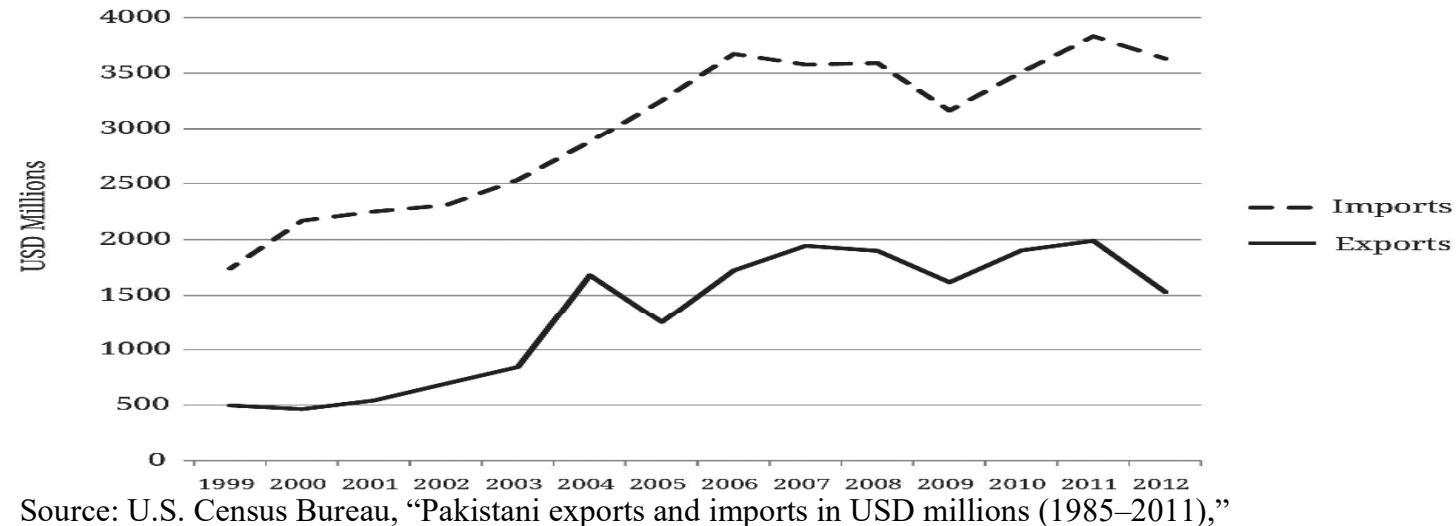


In outline, U.S.- Pakistan business are disorderly not just for the rationale of opposite strategic and nationalized prosperity, however because of rudimentary mistaken assumptions, essentially by American planners, concerning Pakistan and what Washington be able to assume as of Pakistan. Pakistan has been encouraged by US by means of staying away from the obligations. This may illuminate why once in a while Pakistani pioneers and entertainers may pick to work with fear based oppressor and essential Islamist bunches as these substances have the ability to utilize animosity to acquire political privileges from Pakistan's political advantaged. The U.S.-Pakistan discrepancy in constructivist main beliefs together with simply short-range pragmatist agreement in severe difference to the U.S.-India long-standing union of mutually pragmatist and constructivist principles transform into the differential conduct meted out by the U.S. to India and Pakistan. The geopolitical actuality borne in the apparent capability of India as a counter-weight to China gives better dominance to an American association with India than it does to one with Pakistan. In providing Pakistan with armed forces and economic aid, the U.S. was looking for Pakistan's assistance in opposing the Soviet existence in Afghanistan.

As expressed by Haqqani, U.S. inspirations watchful meant for an alliance by way of Pakistan have been various as of Islamabad's explanations behind obliging it. As an end product, Pakistan has been over and over defeated that the U.S. does not add to its suspicions of Indian amazingness on the region, at the same time as Washington has been going through an extra duty commencing Pakistan in the conflict not for Communism and fear based oppression, instead of occupying monetary and military prevention to address India's tough direction capacities. The U.S. reinforced Pakistan's armed forces part observation and gave assistance to extension, yet at a similar example light absolutist and regular propensities in the nation, simultaneously through Islamists. global geopolitical contemplations allowed Pakistan to acquire soothe from the U.S., exclusive of allege as of obligation, for example, going along with US-drove security agreements to obstruct China. Pakistan turned out to be most joined accomplice of US in 1950s comprised Soviet extension.

The political arrangement of Pakistan has since been portrayed by persistent interferences of the real request simultaneously by way of the association of regrettable and non-practical political foundations and the rushed opportunity of the job of the British-prepared armed forces custom special in the political game-plan. Such a requesting and thick living being thoroughly obliges regular citizen intensity of the military. The glitch to standardize top notch matchless quality in Pakistan has caused, all things considered, offense at the countrywide position. A decent amount of veteran and educated locals experience so as to they are unimportant to manage association at the focal and neighborhood point of view. Geo-key contemplations wait deepest to the USPakistan affiliation (Lubna Sunawar and Tatiana Coutto, 2015). The US and Pakistan, together remain consideration modern situation yet in addition have their individual center point of state prosperity (Sehgal, 2010).

On the off chance that we go from start to finish the historical backdrop of Pak-US financial affiliations, we can observer that Pakistan has been being paid significant sympathetic and enhancement help as of US from the time of its initiation. This is a direct way to deal with connect clearly to Pakistani inhabitants and not engaging into disputable plans of Pakistan. In like manner by contributing support contrary to activist gathering, delicately tuned businesses and tenacity of issues troubling their shared affiliations may be valuable in support of their two dimensional affiliations (Neely, 2013). In 2018, a measure of development believer inert progression toward peacefulness conference. In February, President Ghani gave relentless dialogs the Taliban "without any preconditions," despite the fact that the Taliban in purpose of truth push off his recommendation. Ghani stated upon that recommended by recognizing an uneven, everywhere throughout the nation truce in June.

Figure 2. Control of Districts in Afghanistan

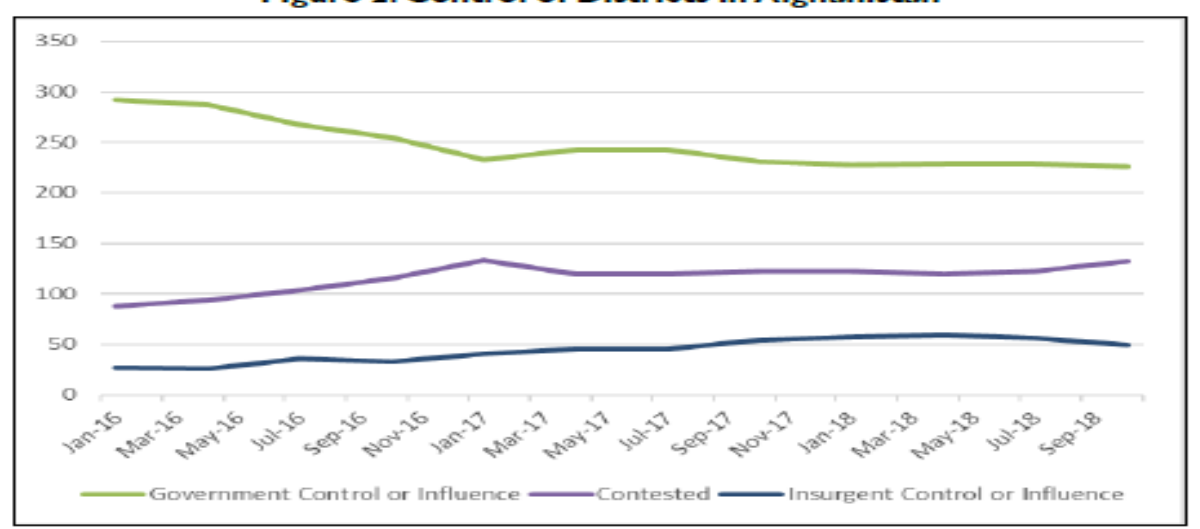

Source: SIGAR Quarterly Reports.

Notes: The $y$-axis represents the number of districts, of which the U.S. government counts 407 in Afghanistan. 
U.S. strategy has NEEDED to convey the Taliban to the giving embark by persuading the place to bind up that supported military extraordinary exertion is vain in light emission U.S., NATO, and ANDSF adequacy. It is at an end ill defined, be that as it may, how the Taliban handle its luxuriousness; indicated the CREW'S cutting edge climbs in 2018, one onlooker has murmured that "the gathering has little intention to commit to a quiet strategy: it is on a spellbinding line."

In any case, shouldn't something be said concerning the piece of the geopolitical rationale at the national phase. Collective protection from the combat gain admittance to a variety expected meant for the principal occurrence in the collapse of 1967 and after that developed greater more point in time (Schmitz, 2005). Up to that point, open conviction had been by and large accommodating of American interest in Indochina, because of clueless media presentation and organization talks that depicted the battle as upright (Herman and Chomsky, 2002). One thought process in this as a rule arranged competition is that, as in the current cataclysm with Iran, exchange advantage frequently request moment continues in the power section, while state agents will in general dispense bigger focus to the long haul results of approach making, for the most part the call meant for to maintain respectability by proposing to likely ADVERSARY that disrespect force debate (Julien Mercille, 2015). The agreement of Pakistan is taunting specified the particular strategy damaged to defeat forceful radicals' in this district has pretty much totally been clandestine CIA automaton impact.

Figure 1: Convergence and divergence, 2000-2015

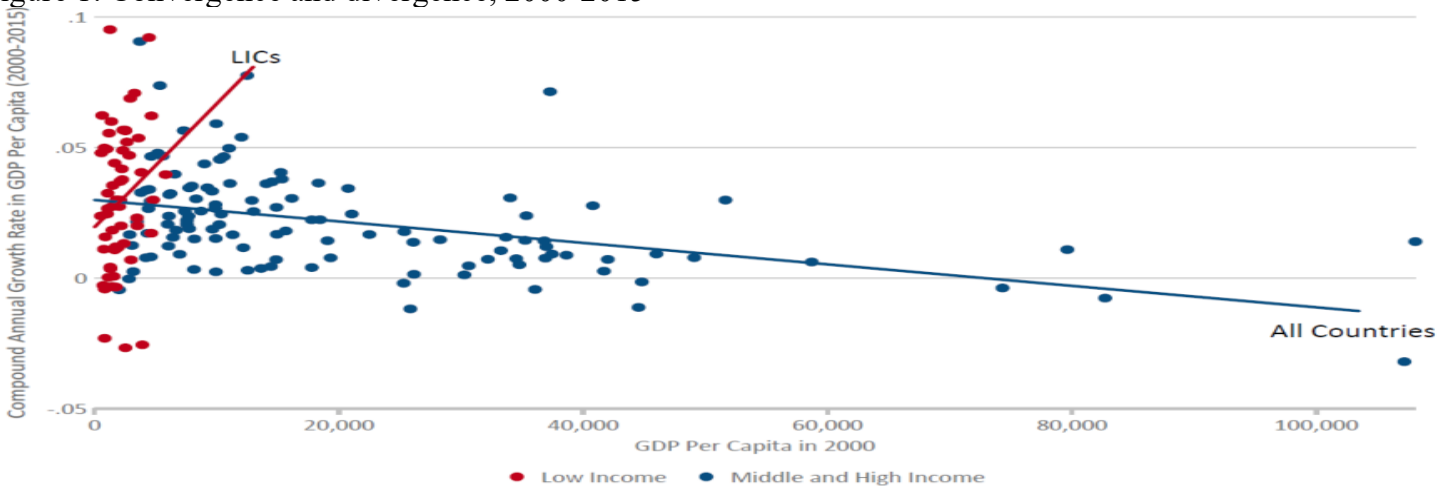

the decrease of extraordinary destitution depends on the believed two patterns to comprehend the worldwide points. Twenty-four nations were distinguished and described as far over the position destitution charge and denied pathway proceedings and are confronting most extreme danger of intensifying to dispose of gigantic neediness by 2030. (Chandy, L. (2017). Asset dependent nations turn out to plot alongside the most troublesome nations, with a highest hazard when most significant article of exchange fares mean with reference to $33 \%$ of Gross Domestic Product (GDP).Countries by method for a close to the position purpose of asset reliance be slanted to be industrialized constitutional government, a bunch essentially padded as of shared wars. Incredibly asset dependent countries in a general sense have oil makers in a spot to 'purchase out' shared congruity as of relatively minute populaces, and bit of leeway on or after the grasp of persuasive local accomplices. There have been repetitive strains and troubles connecting US supremacy and haven targets in the Persian Gulf, together encompassed by and connecting US administration and commerce prosperity. The US control organization was involved in discoursed by way of the Taliban in Afghanistan paying little respect to preeminent revolt from human benefit gatherings, fully expecting its endeavor was finished in late 1998 as the US military responded contrary to al Qaeda's fear monger annoy on the US government office in Nairobi. Regarding more extensive US technique, and scattered from break remunerating remodel contracts and oil assets to US trade advantage, crafted by Iraq and the component of a reactive organization will likely protected greater oil PROVISION to the US and its assembling partners. Bigger expert in the zone, and in the course of it control on OPEC and the oil advertise - not to call attention to the demonstrate of solidarity - possibly will likewise combine the US in its position as the unparalleled worldwide territory, despite the fact that it is unlikely to put a conclusion to brutality. In this gaze, the inconsistencies and limits of the US abroad rules built up that the supreme hold up of local accomplices, for example, Saudi Arabia can energize marital difference, while the approved systems constrained close by 'rebel states', US isn't just on circumstance that assist Pakistan yet in addition a ton of the formative endeavors in Pakistan are bolstered by US. In this vision USAID's activities in Pakistan know how to highlight. USAID education plans facilitated 3.2 million youngsters (Sehgal, Ikram, 2010). US is also sprouting organizations and adventure relationship by methods for India and unfaltering to sustain up organizations to $\$ 500$ billion for every year. What's more, monetary achievement of India is crucial toward the trepidation of strategic points worked out by India and US. US has marked common endeavor agreement with India and foreseen that the completing purpose of the settlement would bring cost in the direction of India and invigorate relationship surrounded by the confidential segments of the two regions. Areas 
draw closer into monetary relationship underneath three points; organizations mitigate and float along with assembling part. As it is right of a wide range of two-sided affiliations, monetary connections along with Pakistan and the US have directed by common put on which is superior than the direction of money related part.

Pakistan's geopolitical significance has been alternative opening from the latter half of the 20th century till the early years of the 21 st. the US does not give the impression to be apprehensive about the beneficiary system as long as the US has other tactical motives dominating the encouragement of democratic system in the Aidreceiving state (Akhter, S. T., \& Imran, H., 2014). A world expansion statement asserts that amount of finances accessible to mounting nations in the type of FDI amplified significantly for the period of mid eighties to 2000.( Ellahi, N., \& Ahmad, M., 2011).

Figure 1: Statistics Showing Trends of FDI and ODA in Pakistan
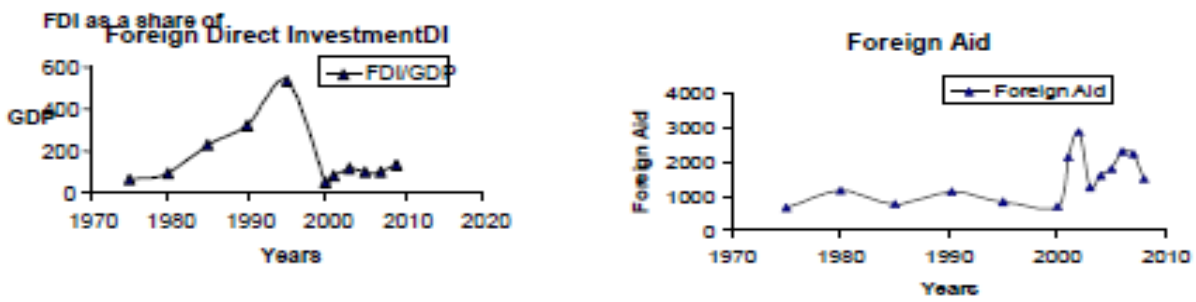

Source: Pakistan Economic Survey, Various issues, and world development indicators.

Political factors be a sign of the steadiness of the legislative policies that are extremely much linked to steady political surroundings. Instable political environment along with numerous changes in the ruling system specify inconsistencies in supremacy and reflecting likely unconstructive belongings on business tricks in the host country. Most of the studies bring to a close that FDI flows to increasing countries are more vulnerable to political environment, as these countries are alleged to be riskier for venture (Shah, Z., \& Ahmed, Q. M. , 2003). Overseas direct venture is an locomotive of growth through which there is augment in technology, capital, capability and revenue.

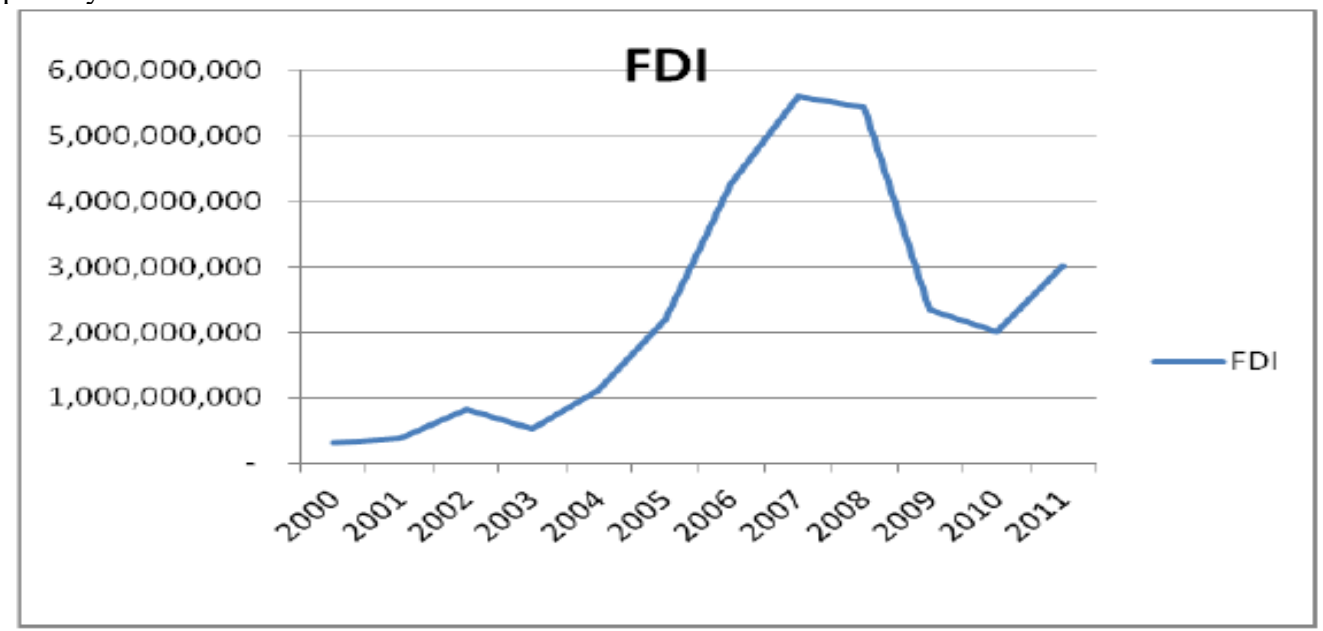

Figure 5.1: Terrorist Attacks in Pakistan

Given figure 5.1 shows the graphical depiction of the numbers of attacks. It is shown that there are uppermost No of fanatic attacks in 2007 which results there is a big dwindle in net overseas direct investment and lowest attacks in 2000 which was constructive for the big raise in growth rate of foreign venture augmentation (Shahbaz, M. A., Javed, A., Dar, A., \& Sattar, T. , 2013).

Aid has proved obliging in inspiring enlargement in the country but on the other hand it has also substituted domestic savings. It has caused a stern liability servicing difficulty and has resulted in additional aid reliance in case of Pakistan (Anwar, M., \& Aman, S. 2010). The consequences propose that support would be further helpful if it were mutual with efforts to promote democratization. Evidently, US support plan for Pakistan has been dependent to a certain extent barely on the accomplishment of instant US foreign policy goals. USAID's own statistics signify how distant the US has faced diminutive of the supercilious standards expressed by President Truman, and certainly the expression of sovereignty and democratic system accommodated by modern American administrations. As time-consuming, this unconcealed disruption of its political expansion carry on, the encouragement of indisputable democratic system, human being civil liberties, fine supremacy, canon of the regulation, and lessening of dearth in Pakistan are expected to linger far-flung imaginings (Ali, M. 2009). 
A phased U.S. moves toward will either reduce this deep-seated uncertainty or call Pakistan's trick about the basis for its actions, inspiring the United States to alter its conduct of Pakistan (Fair, C. C. 2010). Pakistan became nearer to the US for the duration of the succeeding stage of their overseas plan when it depended on American help for political and economic support. Humanitarian support is non-refundable. The American support has first and foremost concerned more political thoughtfulness than humanitarian with a truth that there are hundreds of examples when nations governments and strategies not in the good books of American administrations were deprived of support (Kundi, M. A., 2007). Then again, Afghanistan's financial and political perspective stays uncertain, if not critical, in light of proceeding with hostility. The U.S. furthermore, Afghan civil servants, close by with a scope of nearby states and other overall on-screen characters, have for times involved in diligent work to bring in regards to a political goals through guerillas. At the point when poor countries investigate more quick development in livelihoods than wealthier economies, along these lines decreasing the break in wellspring of income esteems among countries; in this manner investigate that the nation's pace of monetary development per capita is conversely associated to its initial tallness of pay. In any case, United States is seeing extreme worry to develop the area. Likewise, Pakistan is, moreover, hoisting its voice right through the chance of territory associations intended for mounting coordinated effort alongside the region states to find the segment on the way of advancement.

\section{CONCLUSION}

The tactical importance of Pakistan in relation to its peripheral overseas course of action, geopolitical position, etc. stands on its good point. The entire corridor matters (energy, economic, etc.) will be a focus for area and surroundings powers (new Silk Road factor). In this perspective lies the superior worth of U.S.-Pakistan associations in the upcoming. Both countries have invested for sixty years in each other's protection, and it would be a geopolitical calamity if both do not take advantage of on this account of coalition and joint venture. U.S.-Pakistan associations have to go further than the Afghanistan-Pakistan footlights as well as ahead of IndiaPakistan amity. The latter is a strong expansion that opens up improved projection for the whole area. Unluckily, U.S.-Pakistan associations have collapse in 2011, more than in whichever preceding era. Some U.S. civil servants still envision that the nation's basically undersized characteristic resources and additionally geographic circumstance at the intersection of up and coming universal working courses may liven up the financial being of the country, and, by option, its collective and political entries too. To guarantee dependability, the US characterized helps objectives. Political quality is a reason for U.S. impediment, as the U.S. government needs the unwavering quality and determination of outside governments that are anxious to work with the United States. Financial combination and disparity is the principle worry of the arrangements in the beginning of $21 \mathrm{st}$ Century.

Common insight amongst Pakistanis and Americans is that they cannot be good associates. Therefore, there is a need to emphasize a number of current areas where Pak-US wellbeing congregates. Pakistan also had firm economic concern that would be served well if Pakistan sided with US: Pakistan also required US hold up on Kashmir matter, which has for all time been at the hub of Pakistan's overseas strategy. Pakistan has realized the significance of a broader notion of protection with the emphasis on economic and inside constancy.

\section{References}

1. Ahmed, N. (2018). Intraregional Trade within SAARC Nations-A Review. Journal of Business Thought, 8 , 131-138).

2. Akhter, S. T., \& Imran, H. (2014). Geopolitics of International Relations for Pakistan, US Political Regimes and the US Bilateral Aid to Pakistan. GSTF Journal of Law and Social Sciences (JLSS), 4(1).

3. Ali, M. (2009). US Foreign Aid to Pakistan and Democracy: An Overview. Pakistan Journal of Social Sciences (PJSS), 29(2).

4. Andreasen, J. (2014). Foreign Policy Through Aid: Has United States Assistance Achieved its Foreign Policy Objectives?).

5. Anwar, M., \& Aman, S. (2010). Aid effectiveness in education sector of Pakistan. HWWI-Hamburg Institute of International Economics, Research Paper, $16 \mathrm{p}$.

6. Becker, R. A. (2012). Cold War episode: detente and US relations with Pakistan during the 1971 South Asia crisis.

7. Behuria, A. K. (2009). How military dominates the political space in Pakistan: A study of

8. Blank, J., Girven, R. S., Tarapore, A., Thompson, J. A., \& Chan, A. (2018). Vector Check. RAND Corporation.

9. Baloch, Q. B. (2007). Engagement and Estrangement In US-Pakistan Relations. The Dialogue, 1(4), 28-56.

10. Bashir, F., \& Jan, M. A. (2014). Pak-US Relations: Convergence of Interests. PUTAJ-Humanities and Social Sciences, 21(2), 117-133. 
11. Brown, V. F. (2017). President Trump's Afghanistan policy: Hopes and pitfalls.

12. Carpenter, T. G. (1987). A fortress built on quicksand: US policy toward Pakistan. Cato Institute.

13. Chandy, L. (2017). No Country Left Behind: The Case for Focusing Greater Attention on the World's Poorest Countries).

14. Clarke, M. (2016). Value for money: What do developing countries really get from participating in international assessment programs. Worldbank Presentation). Washington.(Online verfügbar unter sitesources. worldbank. org/1818SOCIETY/Resources/Value_for_Money_Clarke_13Jan2016. pdf [01.02. 2016]).

15. Dodds, K. J. (2014). Global geopolitics: A critical introduction. Routledge.

16. Ellahi, N., \& Ahmad, M. (2011, March). Testing the joint impact of foreign aid and foreign direct investment on overtime economic growth of Pakistan. In International Conference on Business and Economic Research. Langkawi Malaysia: World Research Agency.

17. Fair, C. C. (2010). Should Pakistan Get a Nuke Deal?. Foreign Policy, 23.

18. Fleck, R. K., \& Kilby, C. (2008). Changing aid regimes. US foreign aid from the cold war to the war on terror. Villanova School of Business Economics Working Paper, 1.)

19. Friedman, G. (2008). The Geopolitics of India: A Shifting, Self-Contained World. Stratfor, December, 16.

20. Gaens, B., Jokela, J., \& Limnell, E. (Eds.). (2009). The role of the European Union in Asia: China and India as strategic partners. Ashgate Publishing, Ltd.)

21. Hameed, S. (2013). The Future of Cooperation between the United States and Pakistan. Rowman \& Littlefield.

22. Hossain, A., \& Hossain, M. K. (2012). Empirical relationship between foreign direct investment and economic output in South Asian countries: A study on Bangladesh, Pakistan and India. International Business Research, 5(1), 9.

23. Hussain, T. (2005). US-Pakistan Engagement. United States Institute of Peace.

24. Hussain, Z. (2017). The China-Pakistan Economic Corridor and the New Regional Geopolitics. Asia Visions, (94).

25. Innocent, M. (2009). Pakistan and the Future of US Policy. Cato Institute.

26. Iqbal, M. Z. (2010). An appraisal of the Afghanistan-Pakistan strategy to counter terrorism. Parameters, 40(2), 14.

27. Javaid, U., \& Mushtaq, I. (2014). Historical Perspective of Pakistan USA Relations; Lessons for Pakistan. South Asian Studies, 29(1), 291.

28. Javaid, U., \& Siahmardy, H. J. (2017). Globalization, Interdependence and Economic Cooperation Organization (ECO). South Asian Studies (1026-678X), 32(1)).

29. Keohane, R. O., \& Nye Jr, J. S. (1998). Power and interdependence in the information age. Foreign Aff., 77 , 81).

30. Kfir, I. (2014). The Question of Afghanistan and Its Impact on US Relations with Pakistan: The Need for Pragmatic Engagement. Available at SSRN 2523386.

31. Khan, F., \& Masellis, N. (2012). US-Pakistan strategic partnership: A Track II dialogue.

32. Khan, F. J. (2016). 0 The Aid Policy Network in Pakistan: An Actor-Network Analysis (No. 2016: 140). Pakistan Institute of Development Economics.)

33. Khan, I. (2016). Securitization of US Development Policy: The Obama Administration.)

34. Khan, S. A. (2010). The realist/constructivist paradigm: US foreign policy towards Pakistan and India. Strategic Studies, $30(3$ and 4).

35. Khan, Z. A. (2013). Indo-US Civilian Nuclear Deal: The Gainer and the Loser. South Asian Studies (1026$678 X), 28(1)$.

36. Kronstadt, K. A. (2009, February). Pakistan-US relations. Library of Congress Washington Dc Congressional Research Service.

37. Kundi, M. A. (2007). Politics of American aid: The case of Pakistan. Asian Affairs, 29(2), 22-39.

38. Marketos, T. (2009). Eastern Caspian Sea energy geopolitics: a litmus test for the US-Russia-China struggle for the geostrategic control of Eurasia. Caucasian Review of International Affairs, 3(1), 2-19.

39. MEHMOOD-UL-HASSAN, K. H. A. N. (2016). Geopolitics Of CPEC. Politics.

40. Markey, D. S., \& West, J. (2016). Behind China's gambit in Pakistan. Council on Foreign Relations, 5(1).

41. Mercille, J. (2008). The radical geopolitics of US foreign policy: Geopolitical and geoeconomic logics of power. Political Geography, 27(5), 570-586.

42. Middleton, S. L. (2004). The new fight on the periphery: Pakistan's Military relationship with the United States(Doctoral dissertation, Monterey, California. Naval Postgraduate School).

43. Minhas, R. S. A., Reyes Irizarry, J. R., \& Al-Rawashdeh, K. H. (2011). The PAK-US alliance in the fight against terrorism: a cost-benefit analysis.

44. Mollaun, A. H. (2016). US Aid to Pakistan: Nation-Building and Realist Objectives in the Post 9/11 Era. 
45. Mollaun, A. H. (2016). US Aid to Pakistan: Nation-Building and Realist Objectives in the Post 9/11 Era.

46. Mullick, F., \& Yusuf, M. IDENTITY, IDEOLOGY \& BEYOND

47. Musharraf's rule (1999-2008). Journal of peace studies, 16(1-2), 76-102.

48. Owens, M. T. (1999). In defense of classical geopolitics. Naval War College Review, 52(4), 59-76.

49. Rafique, N. (2011). Rethinking Pakistan-US relations. Strategic Studies, 31(3), 124-152.

50. Rennack, D. E., \& Foreign Affairs, Defense, and Trade Division. (2003, February). India and Pakistan: US Economic Sanctions. Congressional Research Service, Library of Congress.

51. Roy, O. (2002). Islamic radicalism in Afghanistan and Pakistan. UNHCR.

52. Shahzad, A., Mithani, D. A., Al-Swidi, A. K., \& Fadzil, F. H. (2012). Political stability and the foreign direct investment inflows in Pakistan. British Journal of Arts and Social Sciences, 9(2), 199-213.

53. Shahbaz, M. A., Javed, A., Dar, A., \& Sattar, T. (2013). Impact of terrorism on foreign direct investment in Pakistan. Archives of Business Research, 1(1).

54. Shah, Z., \& Ahmed, Q. M. (2003). The determinants of foreign direct investment in Pakistan: An empirical investigation. The Pakistan Development Review, 42(4), pp-697.1

55. Stokes, D., \& Waterman, K. (2018). Beyond balancing? Intrastate conflict and US grand strategy. Journal of Strategic Studies, 41(6), 824-849).

56. Sunawar, L., \& Coutto, T. (2015). US Pakistan Relations during the Cold War. The Journal of International Relations, Peace Studies, and Development, 1(1), 6.

57. Waheed, A. W. (2017). Pakistan's Dependence and US Patronage: The Politics of 'Limited Influence'. Journal of Asian Security and International Affairs, 4(1), 69-94.

58. Welt, C. (2018). Russia: Background and US Policy. Current Politics and Economics of Russia, Eastern and Central Europe, 33(3/4), 167-254.

59. Wazir, M. M. K. (2011). Geopolitics of FATA after 9/11. IPRI Journal, 11(1), 59-76.

60. Zaman, A. (2015). Compliance and defiance in patron-client state relationships: a case study of Pakistan's relationship with the United States, 1947-2013. 